\title{
First record of Okenia problematica Pola, Paz-Sedano, Macali, Minchin, Marchini, Vitale, Licchelli et Crocetta, 2019 (Gastropoda Nudibranchia Goniodorididae) for Sicily (Ionian Sea, Italy)
}

\author{
Andrea Lombardo \& Giuliana Marletta \\ Department of Biological, Geological and Environmental Sciences - Section of Animal Biology, University of Catania, via Androne \\ 81, 95124 Catania, Italy \\ Corresponding author, e-mail: andylombardo94@gmail.com
}

\begin{abstract}
Okenia problematica Pola, Paz-Sedano, Macali, Minchin, Marchini, Vitale, Licchelli \& Crocetta, 2019 (Gastropoda Nudibranchia Goniodorididae) is here reported for the first time for Sicily. The Mediterranean species of the genus Okenia Menke, 1830 have recently undergone a taxonomic revision that has reduced the number of species from eight to six because in the past some species were misidentified. For this reason, this new species was described for the Mediterranean. In this short paper, two specimens of this species were found in two nearby areas of Catania (Ionian coast of Sicily) that are strongly anthropized. Therefore, we believe that this species is tolerant to polluted waters.
\end{abstract}

KEY WORDS $\quad$ Goniodorididae; new record; Nudibranchia; Okenia problematica; Sicily.

Received 17.11.2019; accepted 12.02.2020; published online 22.02.2020

\section{INTRODUCTION}

The genus Okenia Menke, 1830 (Gastropoda Nudibranchia Goniodorididae) has a worldwide distribution with 62 species (MolluscaBase, 2019). The species of this genus have a broad body, flattened oral veil, mantle ridge reduced, bearing a variable number of elongated papillae. Similar papillae may be present on the central part of the dorsum (Thomson \& Brown, 1984). According to Pola et al. (2019), in the Mediterranean Sea there are six valid species: O. aspersa (Alder et Hancock, 1845), O. elegans (Leuckart, 1828), O. hispanica Valdés et Ortea, 1995, O. mediterranea (Ihering, 1886), O. longiductis Pola, Paz-Sedano, Macali, Minchin, Marchini, Vitale, Licchelli et Crocetta, 2019, and $O$. problematica Pola, Paz-Sedano, Macali, Minchin,
Marchini, Vitale, Licchelli et Crocetta, 2019. These latter two species have been recently described, in view of a taxonomic revision of this genus in the Mediterranean Sea (Pola et al., 2019). In fact, in previous studies, some species recorded for the Mediterranean basin, in particular O. impexa Er. Marcus, 1957 and O. cupella (Vogel et Schultz, 1970), were repeatedly misidentified. This misidentification could be related to the external similarities, such as the color pattern and the characteristic tip of the papillae (Pola et al., 2019). Okenia impexa and O. cupella are valid species in their type localities that are located in the western Atlantic Ocean. Nevertheless, they were sometimes considered as synonyms and Mediterranean Sea records were assigned to one or the other taxon, according to different authors. Okedia cupella was described by Vogel \& 
Schultz (1970) in York River (Virginia, Atlantic Ocean). In the Mediterranean Sea, the reports ascribed to this species were in Spain: Cabo de Palos (Valdés \& Ortea, 1995), Islas Columbretes (Templado et al., 2002), and Estrecho de Gibraltar (Valdés \& Ortea, 1995; García-Gómez et al., 2011); and in Italy: Ischia (Sordi, 1974 as O. pusilla). On the other hand, O. impexa was described by Er. Marcus (1957) in São Sebastião (Brasil, Atlantic Ocean). The Mediterranean Sea records ascribed to this species were in Spain: Cabo de Palos (Templado, 1982) and L'Escala (Ballesteros et al., 2016); in France: Banyuls-sur-mer (Schmekel, 1979; Schmekel \& Portmann, 1982 as O. impexa banyulensis Schmekel, 1979); and in Italy: Naples (Schmekel, 1979 as $O$. impexa banyulensis Schmekel, 1979).

According to Pola et al. (2019), all Mediterranean Sea records of both species are now ascribed to a single entity, that is $O$. problematica. This new taxon has been recently described by Pola et al. (2019) from specimens collected in Gallipoli (Italy), Aiguafreda (Spain) and Cala Joncols (Spain).

The aim of this note is to document the first record of $O$. problematica in Sicily.

\section{MATERIAL AND METHODS}

Two specimens of $O$. problematica were found in different sites of the Ionian coast of Sicily (Italy): one individual was found in a station near Ognina (Catania) $\left(37^{\circ} 31^{\prime} 49.1^{\prime \prime} \mathrm{N}-15^{\circ} 07^{\prime} 14.8^{\prime \prime} \mathrm{E}\right)$ and the other one in a station called Cannizzaro (Catania) near the Lido Bellatrix $\left(37^{\circ} 32^{\prime} 03.98^{\prime \prime} \mathrm{N}\right.$ $\left.15^{\circ} 07^{\prime} 34.12^{\prime \prime} \mathrm{E}\right)$. The area where the first specimen was found is characterized by rocky boulders of different sizes and small inlets covered with a sciaphilous assemblage. The other site where the second specimen was found is characterized by a rocky steep slide with sciaphilous organisms. Both areas are strongly anthropized. In fact, at Ognina there is a harbor and in both sites there are many bathing establishments and apartment buildings. Both individuals were photographed with an Olympus TG4 underwater camera.

\section{RESULTS}

The first specimen (Figs. 1-3) was seen on 11th
May 2019 near Ognina, at $17.4 \mathrm{mt}$ depth. It was found on a rocky boulder covered by photophilous algae, such as Halopteris scoparia (Linnaeus) Sauvageau. This individual had an elongated body with eight papillae symmetrically distributed on each side of the notum ridge. Papillae were located in this way: in front of rhinophores there were two elongated papillae with a proximal part larger than the distal one; two papillae, at the same level of rhinophores, similar to the previous ones; 4 papillae, between rhinophores and gills, that became longer towards the back and had a more rounded tip, going backwards; two papillae, behind the gills, arising from the same stalk and larger than the previous ones. Among them, one of the right side was smaller than the fellow, because probably it had been previously lost. Another papilla arose alone in front of the gills and was the smallest of the ones hitherto described. Rhinophores bore seven lamellae backwards. Gills were composed of four branches, two anterior and two posterior. The individual had a white translucent body, a pattern of brown spots on the notum, absent on the ridge, between the central papilla and gills. The gills were slightly yellowish.

The second specimen (Figs. 4-6) was seen on 19th May 2019 near the Lido Bellatrix, at $14.5 \mathrm{mt}$ depth. This individual was found above a stone covered by H. scoparia. This specimen was similar to the one found near Ognina, except for two characteristics: the brown pattern which continued beyond the notum, up to half of the sides of metapodium; the absence of one of the last two papillae behind the gills on the left side of the body. Both specimens were photographed "in vivo" and had the same main characteristics of the individuals described by Pola et al. (2019) for $O$. problematica.

\section{DISCUSSION}

These two reports represent the first record of O. problematica for Sicily (Ionian Sea, Italy). Both individuals were found in nearby areas, that are strongly anthropized. Moreover, both specimens were seen almost at the same depth and were both on the same substratum, characterized by the alga $H$. scoparia. Therefore, we believe that $O$. problematica is an euriecia species, tolerating polluted 


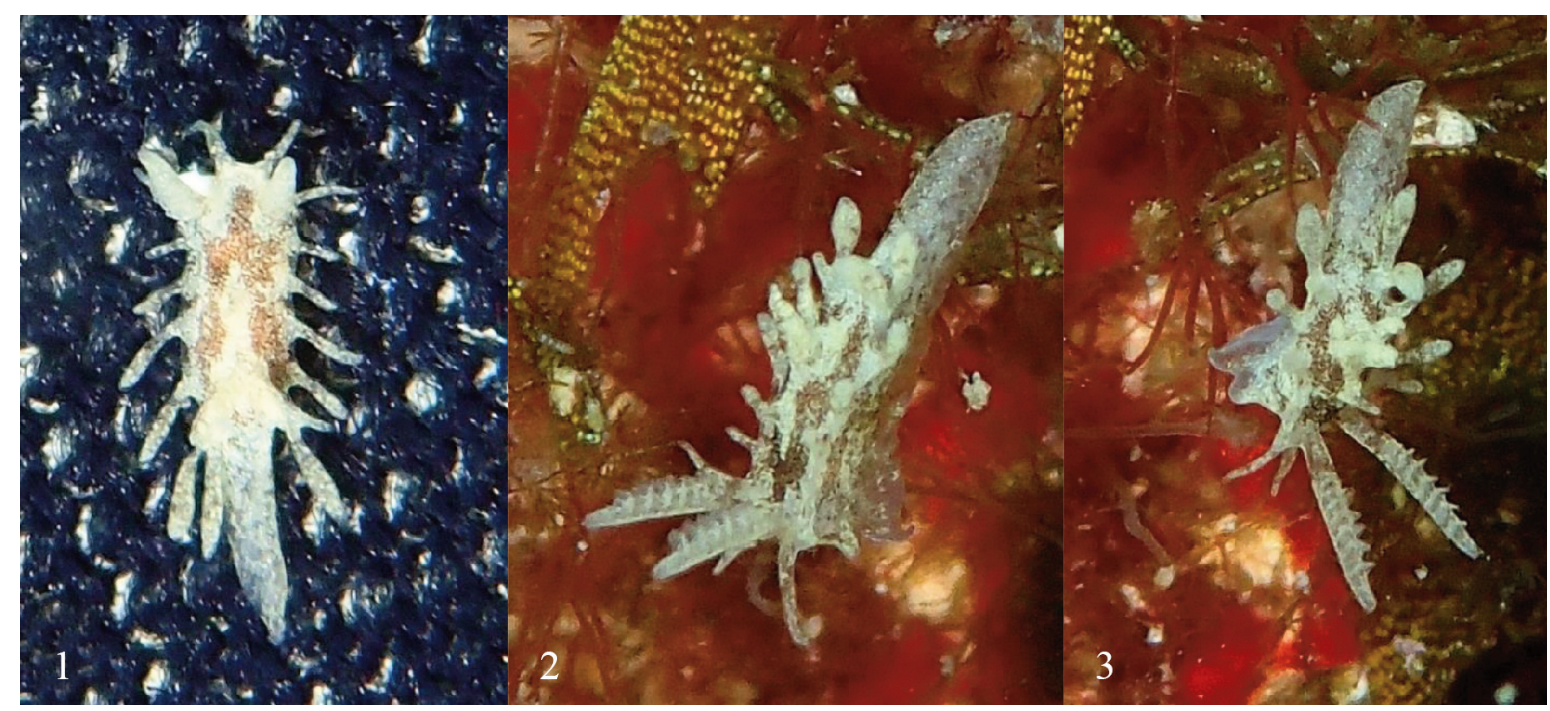

Figures 1-3. Specimen found near Ognina (Catania, Italy). Fig. 1: dorsal view.

Fig. 2: lateral left view. Fig. 3: posterior view (photos by A. Lombardo).

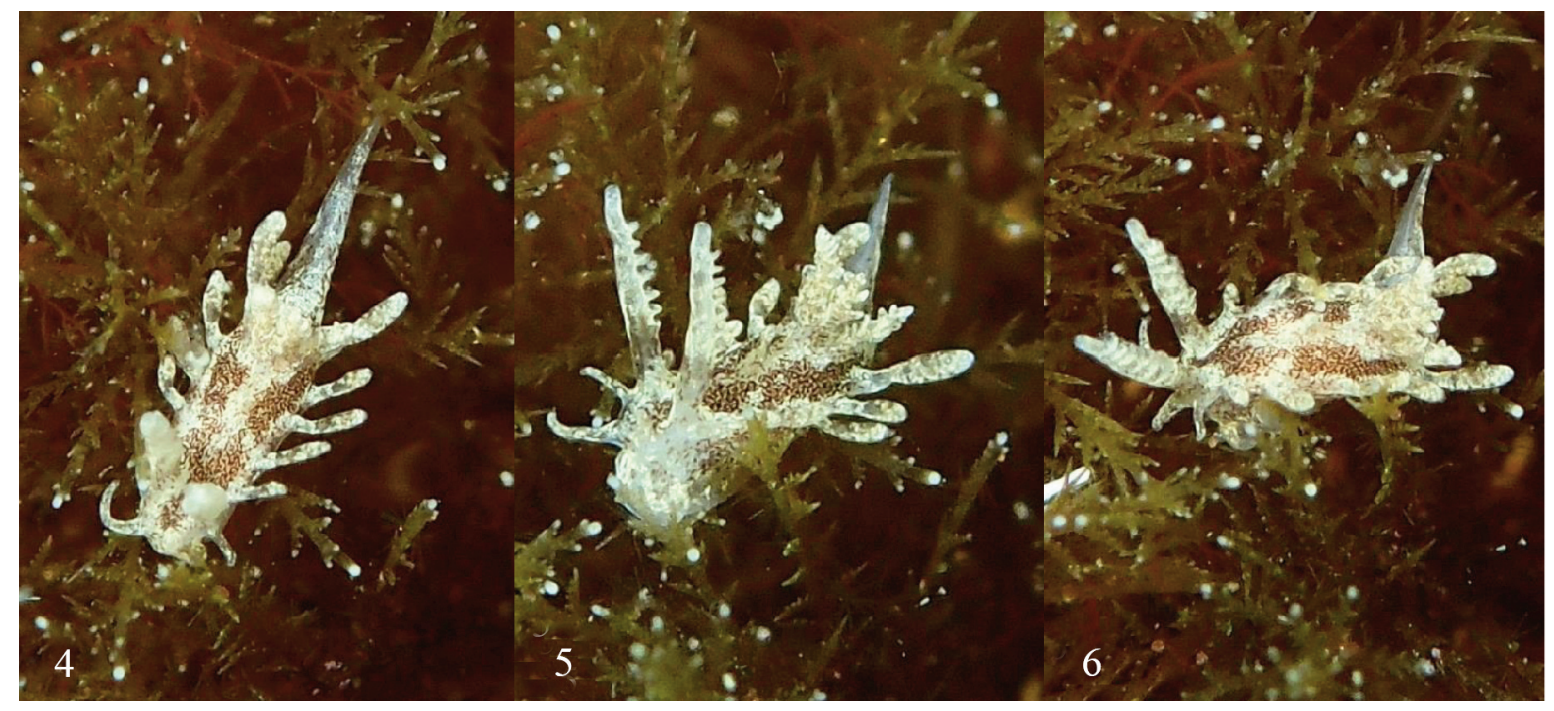

Figures 4-6. Specimen found near Lido Bellatrix (Catania, Italy). Fig. 4: dorsal view.

Fig. 5: anterior view. Fig. 6: lateral left view (photos by A. Lombardo).

waters with a high rate of sedimentation, due to the proximity of the harbor and the coastal exploitation. In fact, we have never found this species in areas of the Ionian coasts of Sicily that are less polluted. Moreover, the other specimens reported in Pola et al. (2019) were found in areas close to cities, which host big harbors. In the previous reports, $O$. problematica was always found in the infralittoral zone (Schmekel, 1979; Schmekel \& Portmann, 1982; Templado, 1982; Valdés \& Ortea,
1995; García-Gómez et al., 2011; Ballesteros et al., 2016; Pola et al., 2019). Even the specimens seen by us were found in the infralittoral zone on a rocky bottoms covered by $H$. scoparia. We think that on this seaweed could live bryozoans which could represent the source of food of $O$. problematica. Finally, we feel that probably this species were already present along the coasts of Sicily, but its cryptic appearance has always making its findings difficult. 


\section{REFERENCES}

Ballesteros M., Madrenas E. \& Pontes M., 2016. Actualización del catálogo de los moluscos opistobranquios (Gastropoda: Heterobanchia) de las costas catalanas. Spira, 6: 1-28. http://www.molluscat.com.sire.ub. edu/spira.html

García-Gómez J. C., Cervera J. L. \& Díaz J., 2011. Familia Goniodorididae. In: Gofas S., Moreno D. \& Salas C., Moluscos Marinos de Andalucía, II. Universidad de Málaga, Servicio de Publicaciones e Intercambio Científico, Málaga, pp. 343-798.

MolluscaBase (2019). MolluscaBase. Okenia Menke, 1830. Accessed through: World Register of Marine Species at: http://www.marinespecies.org/aphia.php? $p=$ taxdetails\&id $=138042$ on 2019-11-12

Pola M., Paz-Sedano S., Macali A., Minchin D., Marchini A., Vitale F., Licchelli C. \& Crocetta F., 2019. What is really out there? Review of the genus Okenia Menke, 1830 (Nudibranchia: Goniodorididae) in the Mediterranean Sea with description of two new species. Plos one, 14(5): e0215037. https://doi.org/ 10.1371/journal.pone. 0215037

Schmekel R.L., 1979. First Record of Okenia impexa
Marcus, 1957 from the Western Atlantic in the Mediterranean. Veliger, 21: 355-360.

Schmekel R.L. \& Portmann A., 1982. Opisthobranchia des Mittelmeeres. Springer-Verlag., Munich, 410 pp.

Sordi M., 1974. Nuova specie di mollusco nudibranchio del Mediterraneo. Doriana, 5 (216): 1-5.

Templado J., 1982. Datos sobre los opistobranquios del Cabo de Palos (Murcia). Bollettino Malacologico, 18: 247-254.

Templado J., Calvo M., García-Carrascosa A., Boisset F. \& Jiménez J., 2002. Flora y fauna de la Reserva Marina de las islas Columbretes. Secretaría General de Pesca Marítima, Ministerio de Agricultura, Pesca y Alimentación, Madrid.

Thompson T.E. \& Brown G.H., 1984. Biology of Opisthobranch mollusks, Vol. 2. The Ray Society, Bristol, 229 pp.

Valdés A. \& Ortea J., 1995. Revised Taxonomy of Some Species of the Genus Okenia Menke, 1830 (Mollusca: Nudibranchia) from the Atlantic Ocean, with the Description of a New Species. Veliger, 38: 223-23.

Vogel R. \& Schultz L., 1970. Cargoa-Cupella New Genus and New Species of Nudibranch from Chesapeake Bay and the generic status of Okenia, Idalia and Idalla. Veliger, 12: 388-393. 